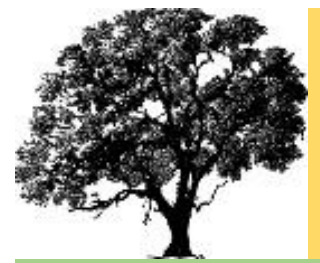

\title{
Türkiye'deki tabiat parklarının rekreasyonel açıdan analizi
}

\author{
Ş.Doğanay Yener ${ }^{1, *}$

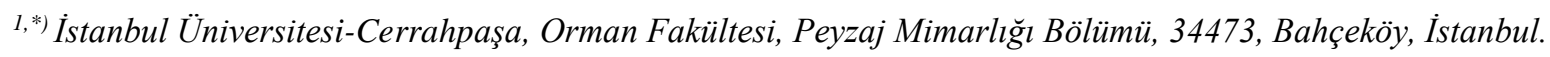

Sorumlu yazar: doganay@iuc.edu.tr

\begin{abstract}
Özet
19. yüzyıl itibariyle teknolojide yaşanan gelişmeler ve tarım devriminin gerçekleşmesiyle kırdan kente göç yaşanarak, hızlı bir kentleşmenin yaşanmaya başlandığı bir döneme geçilmiştir. Bu dönem iki olguyu da beraberinde getirmiştir. İlki kentleşme baskısı altındaki doğal alanların korunma zorunluluğu, diğeri ise kırdan uzaklaşmak zorunda kalan insanın doğada vakit geçirme özlemidir. Günümüzde hızlı nüfus artışıyla beraber insanların rekreasyonel aktivitelerine olanak tanıyan doğadaki bu alanların değeri daha da artmıştır. Bu alanlar içerisinde tabiat parkları sahip olduğu bitki örtüsü ve yaban hayatıyla dikkat çekerken, aynı zamanda kullanıcıların dinlenme ve eğlenme gibi önemli gereksinimlerini karşılamaktadır. Bu çalışma kapsamında Türkiye'deki mevcut tabiat parkları ve bu parkların insanlara sunduğu rekreasyonel aktivitelerin irdelenmesi amaçlanmıştır. Ülkemizdeki mevcut 250 tabiat parkının değerlendirildiği çalışmada, illere göre dağılımları, büyüklükleri ve içerdikleri rekreasyonel aktiviteler ele alınmıştır. Buna göre aktivite ve alt yapı bilgilerine ulaşılan 194 adet tabiat parkında, toplamda 53 farklı rekreatif aktivitenin yapıldığı tespit edilmiştir. En yaygın yapılan aktivitenin doğa yürüyüşü olduğu ve onu takiben sırasıyla fotoğrafçllık ve piknik aktivitelerinin geldiği belirlenmiştir. Son olarak bu alanlar sürdürülebilir kalkınma açısından ele alınarak, gelecek nesillere aktarılmaları ile ilgili önerilerde bulunulmuştur.
\end{abstract}

Anahtar Kelimeler: Doğa koruma, tabiat park1, rekreasyon

\begin{abstract}
As of the 19th century, with the developments in technology and the realization of the agricultural revolution, a period of rapid urbanization began to be experienced, with migration from rural to urban areas. This period brought two phenomena with it. The first is the necessity of protecting natural areas under the pressure of urbanization, and the other is the longing of people who have to move away from the countryside to spend time in nature. Today, with the rapid population growth, the value of these areas in nature, which allow people's recreational activities, has increased even more. While nature parks attract attention with their vegetation and wildlife, they also meet the important needs of users such as resting and entertainment. Within the scope of this study, it was aimed to examine the existing nature parks in Turkey and the recreational activities of these parks. In the study, the existing 250 nature parks in our country were evaluated, their distribution according to the provinces, their sizes and the recreational activities they included were discussed. Finally, these areas were discussed in terms of sustainable development and suggestions were made regarding to their transfer through the future generations.
\end{abstract}

Recreational Analysis of Nature Parks in Turkey

Key words: Nature conservation, nature park, recreation 


\section{Giriş}

Ülkemiz, olağanüstü doğal güzelliklere ve kültürel değerlere sahiptir. Doğal, tarihi ve kültürel miras olarak kabul edilen çok sayıda milli park, tabiat anıtı, tabiatı koruma alanı ve tabiat parkına sahip olması, bunun en güzel göstergelerinden biridir. Bu doğa harikası alanlar aynı zamanda rekreasyonel açıdan yüksek potansiyele sahip olması, mevcut bitki örtüsünün ve yaban hayatının zenginliği, doğal peyzaj çeşitliliği gibi özellikleri nedeniyle insanların kent yaşamındaki yoğunluklarından kurtulduğu ve nefes aldığı alanlar olarak oldukça kıymetlidir. Ekoturizm kavramının giderek yaygınlaştığı günümüzde, insanların bu tür doğal güzellikleri ziyaret etmek ve rekreasyonel ihtiyaçlarını karşılama eğilimi oldukça fazladır.

1983 tarihli 2873 sayılı Milli Parklar Kanununa göre, koruma statüsü verilecek doğal alanların (Milli Parklar, Tabiat Parkları, Tabiatı Koruma Alanları, Tabiat Anıtları) içinde sadece Milli Parklar ve Tabiat Parkları rekreasyon/turizm amaçlarına hizmet edebilecek şekilde belirlenmiştir (Gül ve ark. 2005). Tabiat parkları yine aynı Milli Parklar Kanunu'nda; "Bitki örtüsü ve yaban hayatı özelliğine sahip, manzara büyüklüğü içinde halkın dinlenme ve eğlenmesine uygun tabiat parçalarıdır” şeklinde ifade edilmektedir. Orman ve orman rejimine tabi yerlerde tabiat parkları Orman ve Su İşleri Bakanlığının onayı ile belirlenir. Orman ve orman rejimi dışında kalan yerlerde ise bu alanlar Çevre ve Şehircilik Bakanlığınca tescil edilmektedir (URL-1).

Tabiat parklarının taşıması gereken özelliklerden bazıları; devletin mülkiyetinde, üstün tabii fizyografik yapıya, bitki örtüsü ve yaban hayatı özelliklerine ve manzara güzellikleri ile rekreasyon potansiyeline sahip, kaynak ve manzara bütünlügünü sağlayacak yeterli büyüklükte, özellikle açık hava rekreasyonu yönünden farklı ve zengin bir potansiyele sahip, mahalli örf ve adetlerin, geleneksel arazi kullanma düzeninin ve kültürel manzaraların ilgi çeken örneklerini de ihtiva edebilmelidir (Tekin ve ark. 2014).Türkiye'de tabiat parkı statüsünde toplam 250 adet korunan alan bulunmaktadır. Bu tabiat parklarının, 50'si doğal sit, 7'si arkeolojik sit, 4'ü hem doğal hem arkeolojik sit, 1 tanesi ise hem doğal hem de tarihi sit niteliğindedir. Doğal sit alanı ilan edilmiş olanlar kullanıcılara rekreasyonel açıdan da farklı olanaklar tanımaktadır. Arkeolojik ve tarihi sit alanı olanlar ise kültür turlarına olanak sağlamaları açısından bir cazibe merkezidir. Türkiye'nin ilk tabiat park1 1983 yılında kurulmuş olan Fethiye Ölüdeniz'deki Kıdrak Tabiat Parkı'dır. Burası aynı zamanda doğal sit alanıdır. Daha sonra 1984 yılında Çorum'da Çatak Tabiat Parkı, 1988 yılında ise Bolu'da Abant Gölü Tabiat Parkı olarak ilan edilmiştir.

Tabiat parkları ve diğer doğa koruma alanlarının rekreasyonel açıdan değerlendirilmelerini konu alan çok sayıda çalışma (Akten ve Gül 2014, Altunöz ve ark. 2014, Dal ve Karayılmazlar 2019, Gül ve ark. 2005, Kaptan Ayhan, 2019, Özçalık ve Kumru 2019, Öztürk ve Gül 2020, Polat ve Aktaş Polat 2016, Sezer ve Bekdemir 2017, Surat ve ark. 2014, Şahbaz ve Altınay 2015) mevcuttur. Bu çalışmalar, genel olarak rekreasyon aktivitelerine yönelik potansiyelin belirlenmesine yönelik gerçekleştirilmiş olup, alanların rekreasyonel açıdan uygunluğuna odaklanmışlardır.

Kullanıcılar için farklı rekreasyon olanakları sunuyor olması şüphesiz tabiat parklarının insanlar için cazip bir yer haline gelmesini sağlayan en önemli özelliklerindendir. Sunulan bu olanakların yerli ve yabancı turist bakımından ülke ekonomisine katkısı oldukça fazladır. Özellikle korunması gereken tabiat alanlarını barındırdıklarını düşünecek olursak, sürdürülebilir kalkınma bağlamında bu alanları ele almak daha doğru olacaktır. Bu tabiat parkları bugünün kullanıcılarının gereksinimlerini karşılarken, gelecek nesillerin ihtiyaçlarını da karşılayabilecek nitelikte olması gerekir. Tabiat parklarının planlamaları yapılırken, koruma kullanma dengesi gözetilmeli ve de gelecek nesillere miras bırakılması gereken değerli alanlar oldukları gerçeği her zaman ön planda tutulmalıdır. 
Tabiat parklarının rekreasyonel açıdan uygunlukları ve potansiyelleri detaylı olarak araştırılmış olsa da, mevcut tabiat parklarının sunduğu rekreasyon faaliyetlerinin genel karakterini ve bu alanlardaki alt yapı/donatı özelliklerinin detaylı irdelenmediği görülmüsşür. Bu kapsamda şekillenen bu çalışma, Türkiye'deki tabiat parklarının sundukları rekreasyon faaliyetlerini ve alt yapı/donatılarını irdelemeyi amaçlamaktadır. $\mathrm{Bu}$ amaç doğrultusunda ülkemizdeki mevcut 250 tabiat park1 sistematik olarak değerlendirilmiş ve analiz edilmiştir. $\mathrm{Bu}$ analiz çerçevesinde tabiat parklarındaki rekreasyonel faaliyetler ve alt yapı/donatı özellikleri irdelenerek öneriler geliştirilmiştir.

\section{Malzeme ve Yöntem}

Çalışmanın ana materyalini Türkiye'de mevcut bulunan tabiat parkları ve bunların içerdiği rekreasyonel aktiviteler oluşturmaktadır. Tabiat parkları ile ilgili verilerin temini için Doğa Koruma ve Milli Parklar Genel Müdürlüğü resmi web sitesinden yararlanılmıştır (URL-2). Daha sonra tabiat parklarnın rekreasyonel aktiviteleri ile alt yap1 ve donat1 elemanlarına ait veriler 2 grup altında incelenerek, excel dosyalarına işlenmiş ve ayrı ayrı analiz edilmiştir. Yapılan değerlendirmelerde 250 tabiat parkının 239'unun bulundukları il, tabiat park1 ilan edilme tarihleri ve alan büyüklüklerine ait bilgilere ulaşılmıştır (Tablo 1). Rekreasyonel aktiviteleri açısında ise sadece 194 tabiat parkına ait detaylı bilgiye ulaşılmıştır.

Ülke genelinde toplam 46 tabiat parkı ile ilişkili olarak hiçbir aktivite bilgisine ulaşılamamıştır. Aktivite bilgisine ulaşılamayan tabiat parklarının büyük çoğunluğu Karadeniz bölgesinde bulunmakta olup; Cehennem Deresi Kanyonu, Tavşan Tepesi, Geyiklibel Kanyonu, Aymaç, Harşit, Köroğlu, Şaban Kalesi, Baklabostan, Akgöl, Çatak kanyonu, Çamburnu, Sis Dağı ve Göl Dağı tabiat parklarıdır. Marmara Bölgesi'nde yer alıp hiç aktivite bilgisi bulunmayan tabiat parkları ise; Sarıklı, Erikli, Kınık Şelalesi, Vakıf, Danamandıra, Hacet Deresi ve Türkmenbaşı tabiat parklarıdır. Ege Bölgesi'nde yer alıp hiç aktivite bilgisi bulunmayan tabiat parkları; Erkmen, Frig Vadisi, Yedikap1, Ekmeksiz Plajı, İnbükü, Kovanlık ve Göğem-Zafer tabiat parklarıdır. Akdeniz Bölgesi'nde yer alıp hiç aktivite bilgisi bulunmayan tabiat parkları; Obruk Şelalesi, Karanlıkdere Kanyonu, Şahin Tepesi, Sarıkayalar ve Şehitlik tabiat parklarıdır. İç Anadolu Bölgesi'nde yer alıp hiç aktivite bilgisi bulunmayan tabiat parkları; Durusan Şah, Yunus Emre, Kuğulu, Canköy, Karşıyaka, Oymalık tabiat parklarıdır. Doğu Anadolu Bölgesi'nde yer alıp hiç aktivite bilgisi bulunmayan tabiat parkları; Dumanlı, Esentepe, Keklikkayası ve Günpınar Şelalesi tabiat parklarıdır. Güneydoğu Anadolu Bölgesi'nde yer alıp hiç aktivite bilgisi bulunmayan tabiat parkları; Doğanlı, Eğil Peygamberler, Gaziantep Milli Mücadele ve Gap Şelaleleri tabiat parklarıdır.

\section{Bulgular}

\section{Türkiye'deki Tabiat Parklarına İlişskin Genel Bulgular}

Türkiye'deki tabiat parklarının illere göre dağılımlarına baktığımızda en çok tabiat parkı İstanbul ilinde (26 adet) bulunmaktadır. Onu takiben 10 tabiat parkı ile Ankara ili ve 9 tabiat parkı ile Mersin, Muğla ve Bolu illeri gelmektedir. Tabiat parkı bulunmayan 11 ilimiz mevcuttur. Bunlar; Ağr1, Aksaray, Bingöl, Bitlis, Hakkari, Iğdır, Karaman, Nevşehir, Niğde, Şırnak, Van'dır (Şekil 1).

1984'ten günümüze Türkiye'deki tabiat parklarının ilan ediliş yıllarına baktığımızda, büyük bir çoğunluğunun (toplam 205 tabiat parkının) son 10 y1l içerisinde (2011-2019) ilan edilmiş olduğu görülmektedir (Şekil 2). 
Tablo 1. Çalışma kapsamında incelenen tabiat parklarının illere göre dağılımı ve toplam büyüklükleri

\begin{tabular}{|c|c|c|c|c|c|}
\hline İl adı & TP sayısı & Alan (ha) & $\overline{\text { İl adı }}$ & TP sayısı & Alan (ha) \\
\hline Balıkesir & 4 & 19661,19 & Malatya & 3 & 248,93 \\
\hline Denizli & 1 & 14692,33 & Bayburt & 1 & 208 \\
\hline Aydın & 4 & 11928,84 & Şanlıurfa & 1 & 204,75 \\
\hline Isparta & 3 & 6473,3 & Eskişehir & 2 & 190 \\
\hline Gümüşhane & 6 & 6029,32 & Mersin & 9 & 175,35 \\
\hline İstanbul & 26 & 5036,18 & Uşak & 2 & 173,21 \\
\hline Adana & 4 & 4659,38 & Kütahya & 3 & 159,84 \\
\hline Rize & 4 & 4589,35 & Sinop & 3 & 154,62 \\
\hline Kocaeli & 8 & 3441,53 & Hatay & 2 & 135,41 \\
\hline Bolu & 9 & 3021,12 & Diyarbakır & 1 & 134,14 \\
\hline Artvin & 5 & 2689,37 & Kırşehir & 1 & 127,59 \\
\hline Trabzon & 7 & 2196,74 & Kırıkkale & 1 & 107,53 \\
\hline Samsun & 5 & 2157,6 & Zonguldak & 4 & 103,35 \\
\hline Adiyaman & 2 & 2085,28 & Edirne & 3 & 101,74 \\
\hline Burdur -Muğla & 1 & 1775 & Batman & 1 & 96 \\
\hline Giresun & 8 & 1101,63 & Burdur & 2 & 95,38 \\
\hline Ankara & 10 & 1064,8 & Bartın & 3 & 72,45 \\
\hline Gaziantep & 5 & 962,53 & Kilis & 1 & 64 \\
\hline Konya & 4 & 923,54 & Mardin & 1 & 52,78 \\
\hline Tokat & 2 & 885,86 & Ardahan & 1 & 50,57 \\
\hline Erzincan & 3 & 739,49 & Osmaniye & 1 & 50 \\
\hline Çorum & 2 & 697,16 & Muş & 1 & 40 \\
\hline Antalya & 4 & 677,51 & Siirt & 1 & 40 \\
\hline Bilecik & 4 & 637,95 & Karabük & 1 & 37,4 \\
\hline Çankırı & 3 & 584,41 & Kırklareli & 1 & 35,55 \\
\hline Yozgat & 5 & 525,38 & Yalova & 2 & 23,76 \\
\hline Kahramanmaraş & 2 & 519,18 & Elazığ & 1 & 22,5 \\
\hline İzmir & 8 & 507,66 & Kastamonu & 3 & 20,86 \\
\hline Bursa & 2 & 479 & Ordu & 2 & 20 \\
\hline Düzce & 4 & 411,94 & Sivas & 1 & 17,99 \\
\hline Muğla & 9 & 408,4 & Kayseri & 1 & 17,37 \\
\hline Afyonkarahisar & 4 & 389,23 & Manisa & 2 & 16,87 \\
\hline Sakarya & 3 & 376,36 & Tunceli & 1 & 15,55 \\
\hline Tekirdağ & 2 & 299,14 & Kars & 1 & 11 \\
\hline \multirow[t]{2}{*}{ Amasya } & 1 & 259,6 & Çanakkale & 1 & 5,85 \\
\hline & & & Genel Toplam & 239 & 105917,6 \\
\hline
\end{tabular}

Toplamda ülkemizdeki 54 tabiat parkının doğal sit varlığına sahip olduğu görülmektedir. Doğal sit niteliğindeki tabiat parklarımızın 15 tanesi İstanbul ilinde yer almaktadır. İkinci en fazla doğal sit niteliğindeki tabiat parkı içeren ilimiz Muğla'dır (7 adet). Onu takiben Trabzon ve İzmir'de 3'er tane doğal sit niteliğinde tabiat parkı mevcuttur. Bu tabiat parklarından en büyükleri ise 19624 ha ile Ayvalık Adaları (Balıkesir), en küçüğü ise 1,59 ha'lık alanı ile Sarımsaklı (Balıkesir) Tabiat Parkı'dır. İkinci büyük doğal sit varlığına sahip tabiat parkı ise 11842 ha alanı ile Aydın ilindeki Bafa Gölü’dür (Tablo 2). 


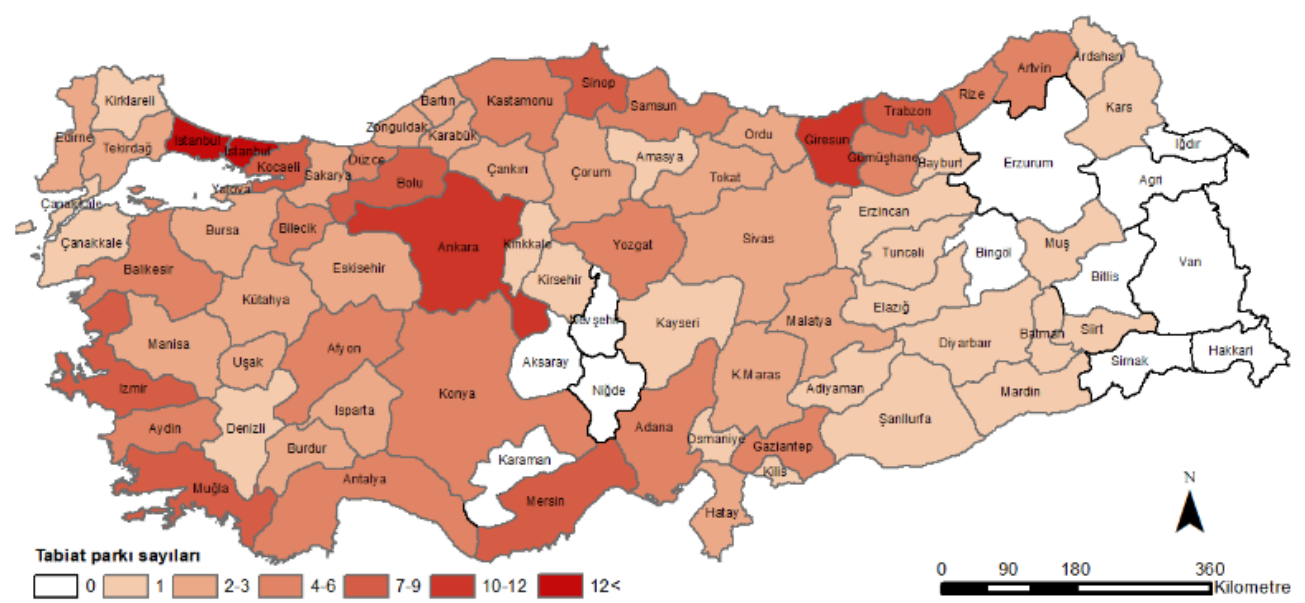

Şekil 1. Tabiat parklarının illere göre dağılımı

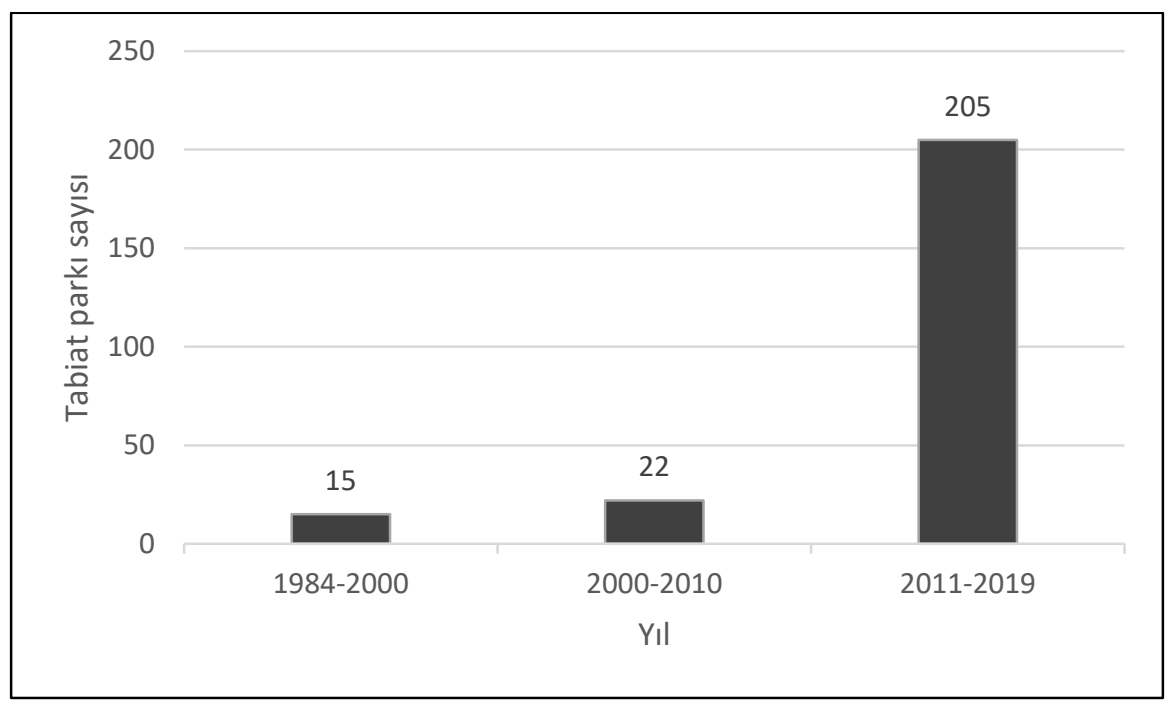

Şekil 2. Tabiat parklarının ilan ediliş yıllarına göre dağılımı

Tablo 2. Doğal sit varlığına sahip tabiat parkları ve büyüklükleri

\begin{tabular}{llllll}
\hline Tabiat parkı adı & İl adı & Alan ha. & Tabiat parkı adı & İl adı & Alan ha. \\
Ayvalık Adaları & Balıkesir & 19624 & Tanay & İzmir & 30 \\
Bafa Gölü & Aydın & 11842 & Marmaracık Koyu & İstanbul & 27 \\
Gölcük (Isparta) & Isparta & 5888 & Vakıf & Edirne & 27 \\
Polonezköy & İstanbul & 2931 & Ölüdeniz - Kıdrak & Muğla & 25 \\
Altıparmak & Artvin & 2111 & Aydıncık & Mersin & 24 \\
Gölbaşı Gölleri & Adıyaman & 2080 & Mehmet Akif Ersoy & İstanbul & 24 \\
Uzungöl & Trabzon & 1642 & Sera Gölü & Trabzon & 22 \\
Ballıkayalar & Kocaeli & 1603 & Çiçekli & İzmir & 21 \\
Beşkayalar & Kocaeli & 1100 & Çubucak & Muğla & 21 \\
Ballıca Mağarası & Tokat & 485 & Mihrabat & İstanbul & 20 \\
Sadağı Kanyonu & Bursa & 436 & F. Rıfkı Atay & İstanbul & 19 \\
Danamandıra & İstanbul & 381 & Kirazlıbent & İstanbul & 19 \\
Kocakoru Ormanı & Konya & 331 & Bentler & İstanbul & 16 \\
İnbükü & Muğla & 286 & Küçük Kargı & Muğla & 15 \\
Boraboy & Amasya & 260 & Usuluk Koyu & Muğla & 14 \\
Poyrazlar Gölü & Sakarya & 231 & Danişment & Edirne & 13 \\
Kelebekler Vadisi & Ankara & 177 & Değirmenburnu & İstanbul & 13 \\
Günpınar Şelalesi & Malatya & 135 & Elmasburnu & İstanbul & 13 \\
\hline
\end{tabular}




\begin{tabular}{lllll}
\hline Kayabaşı & Trabzon & 134 & Ekmeksiz Plajı & İzmir \\
İl Ormanı & Sakarya & 103 & Irmak & İstanbul \\
Tatlıca & Sinop & 72 & Dilburnu & İstanbul \\
Hamsilos & Sinop & 68 & Tomara Şelalesi & Gümüşhane \\
Neşetsuyu & İstanbul & 67 & Kovanlık & Muğla \\
Göztepe & İstanbul & 59 & Ömer Eşen & Muğla \\
Salda Gölü & Burdur & 57 & Büyükada & İstanbul \\
Suuçtu & Bursa & 43 & Kömürcübent & İstanbul \\
Cehennem & Artvin & 32 & Sarımsaklı & Balıesir \\
\hline
\end{tabular}

\section{Rekreatif Aktiviteler Açısından Tabiat Parklarına İlişkin Bulgular}

Türkiye'de tabiat parklarında yapılan aktiviteler Tablo 3'te sıralanmıştır. Ülke genelinde toplamda 53 farklı rekreatif aktivitenin tabiat parklarında yapıldığı görülmektedir. Buna göre \%72,34 oranı ile 'doğa yürüyüşü' en fazla yapılan aktivite olma özelliğindedir. İkinci sırada $\% 63,83$ lük oranla 'fotoğrafçıllk' ve üçüncü sırada da \%59,57'lik oran ile 'piknik' aktiviteleri gelmektedir. Yine ülkemizdeki tabiat parklarını aktiviteler bakımından sıralarsak en az yapılan aktiviteler; deve gezintisi, firın, ip parkuru ve pentatlon, mavi gölde yüzme ve trenle göl turudur.

Tablo 3. Tabiat parklarında yapılabilen aktiviteler ve dağılımları

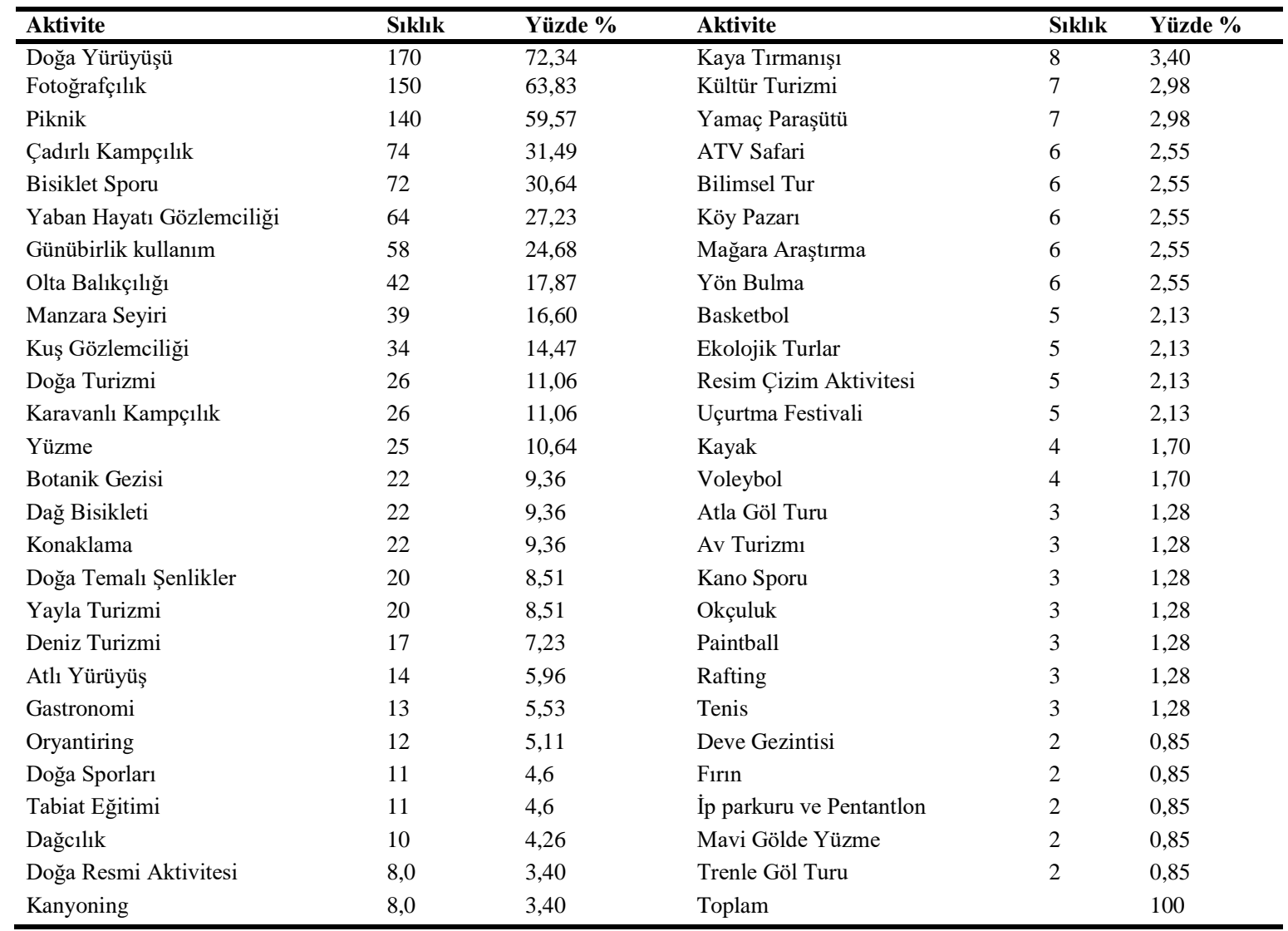

Aktivite zenginliği bakımından en fazla aktivitenin yapılabildiği tabiat parkları Şekil 3'te görülmektedir. Buna göre Karadeniz Bölgesi'nde, Samsun ili sınırları içerisinde yer alan Vezirsuyu tabiat parkı 21 farklı rekreasyonel aktiviteye olanak sağlayarak, ülkemizdeki rekreasyonel aktivitesi en zengin tabiat park1 olma özelliğindedir. Onu takiben en fazla aktivitenin yapılabildiği ikinci tabiat parkı ise yine Karadeniz Bölgesi'nde Bolu ilinde yer alan Abant Gölü Tabiat Parkı'dır. Bu tabiat parkı da 17 farklı rekreasyonel 
aktiviteye olanak tanımaktadır. Harmankaya Kanyonu, Avcıkoru ve Şahinkaya Kanyonu Tabiat Parkları ise 15 farklı aktiviteye sahip diğer rekreasyon açısından zengin parklardandır.

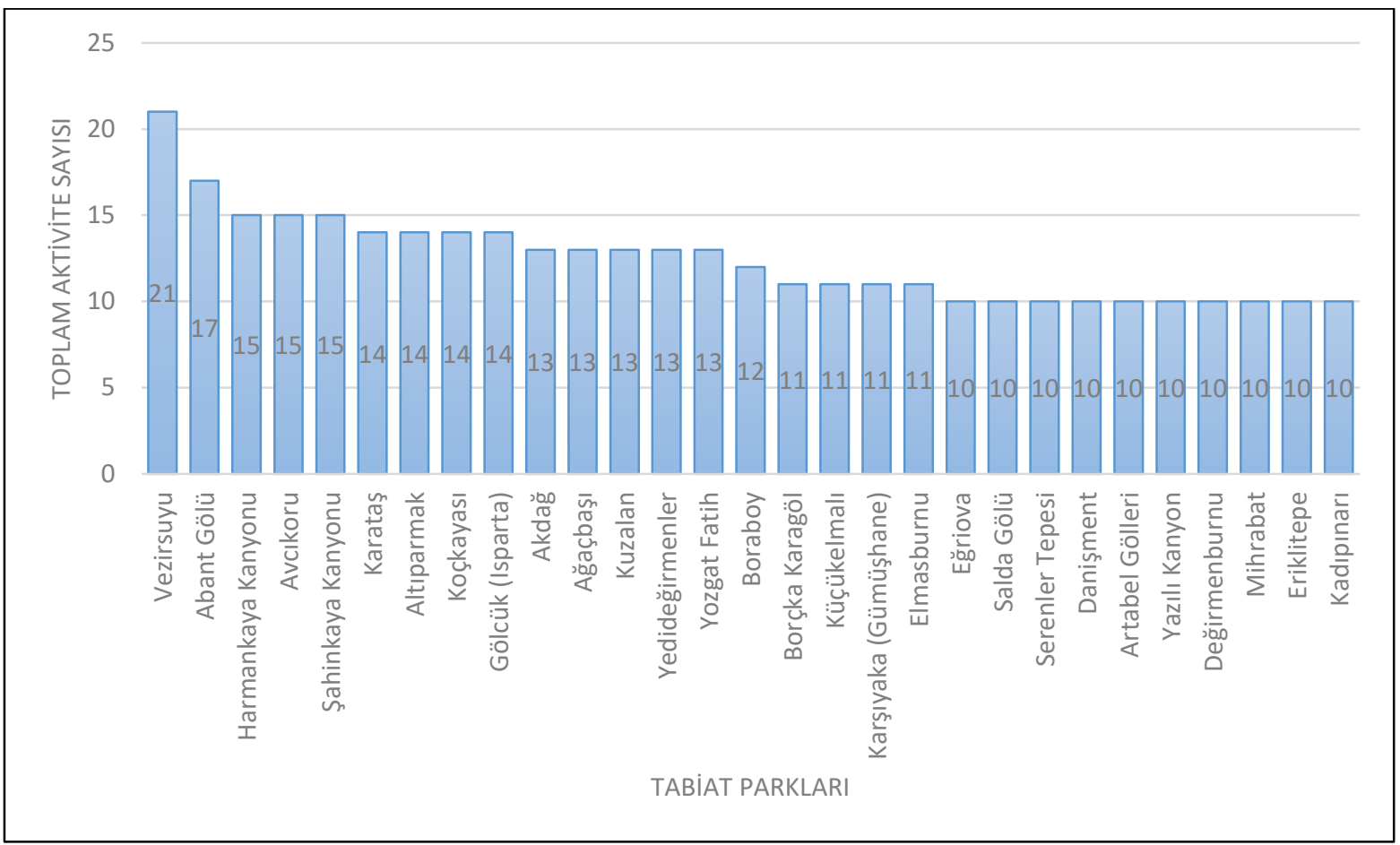

Şekil 3. Aktivite zenginliği en yüksek tabiat parkları

Aktivite zenginliği açısından en az aktivitenin yapılabildiği tabiat parkları Şekil 4'te görülmektedir. Kelebekler Vadisi, Ayazmapınarı, Parkorman, Akyamaç (Hemşin Şelalaleri), Topalçam ve İncüvez Çamlığı Tabiat Parkları tek aktivite olanağı olan parklardandır.

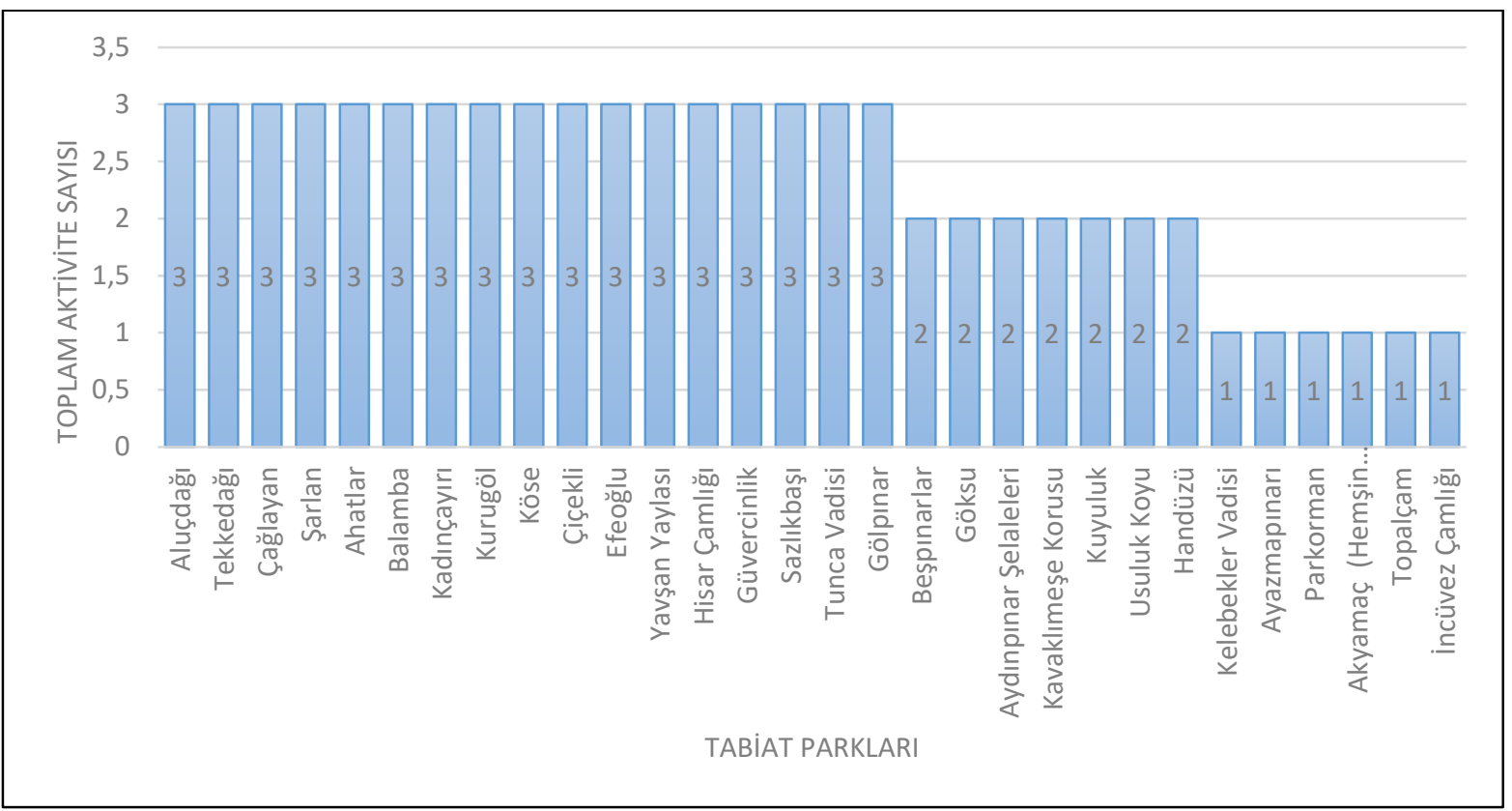

Şekil 4. Aktivite zenginliği en düşük tabiat parkları 
Türkiye'deki tabiat parkları sundukları rekreasyonel aktiviteler açısından değerlendirildiğinde, Akdeniz, Maramara, Karadeniz ve İç Anadolu bölgelerindeki tabiat parkların diğer bölgelerdeki tabiat parklarına göre daha zengin rekreatif imkanlar sağladığı görülmektedir. Şekil 5'e göre, bölgelerin medyan değerlerinin birbirine yakın olduğu, bununla birlikte Ege ve Doğu Anadolu bölgelerindeki tabiat parklarının aktivite zenginliği açısından birbirlerine benzer olduğu anlaşılmaktadır. Karadeniz bölgesinde ise birbirinden olukça farklı sayılarda aktivite sunan tabiat parkının olduğu dikkat çekmektedir (Şekil 5).

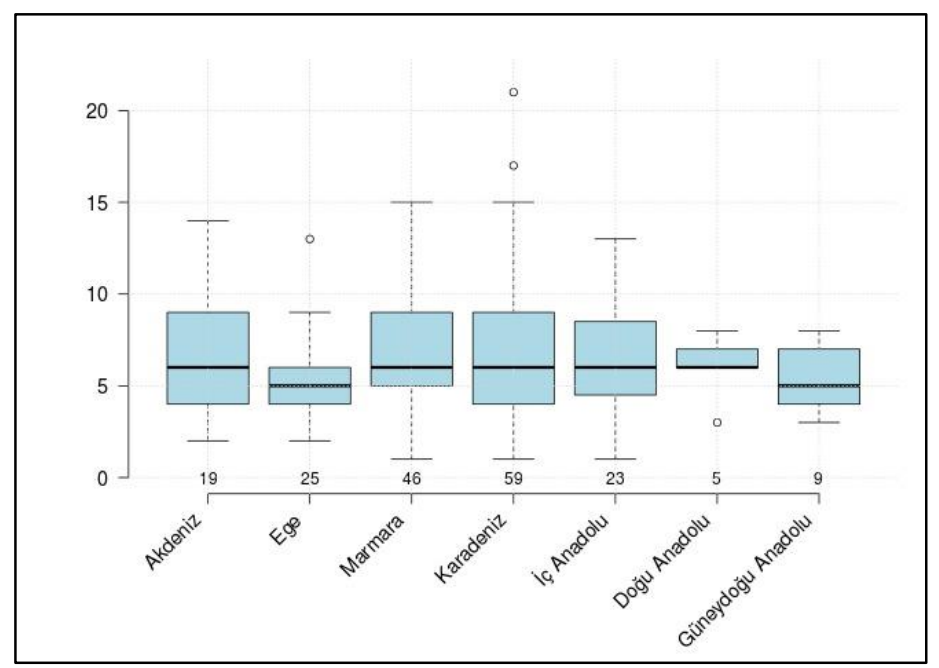

Şekil 5. Bölgelere göre tabiat parklarının dağılımı ve aktivite zenginliği

\section{Tabiat Parklarının Alt Yapı ve Donatı Elemanlarına İlişkin Bulgular}

Türkiye'deki tabiat parklarının fiziksel altyapı olanakları ve donatılar bakımından değerlendirdiğimizde; parkların büyük çoğunluğunda kır gazinosu/kahvesi/lokanta imkanına sahip olduğu görülmektedir. Oldukça önemli ihtiyaçlardan biri olan WC varlığı açısından tabiat parklarını değerlendirdiğimizde ise sadece 139 tanesinde yer aldığını söyleyebiliriz. Yine tabiat parklarının 117'sinde giriş kontrol noktaları yer alırken, 104'ünde çeşme ve 101'inde büfe bulunduğu dikkat çekmektedir. Yine en yaygın bulunan aktivite alanlarından biri çocuk oyun alanı, kameriyeler, piknik alanları ve mescitlerdir (Şekil 6).

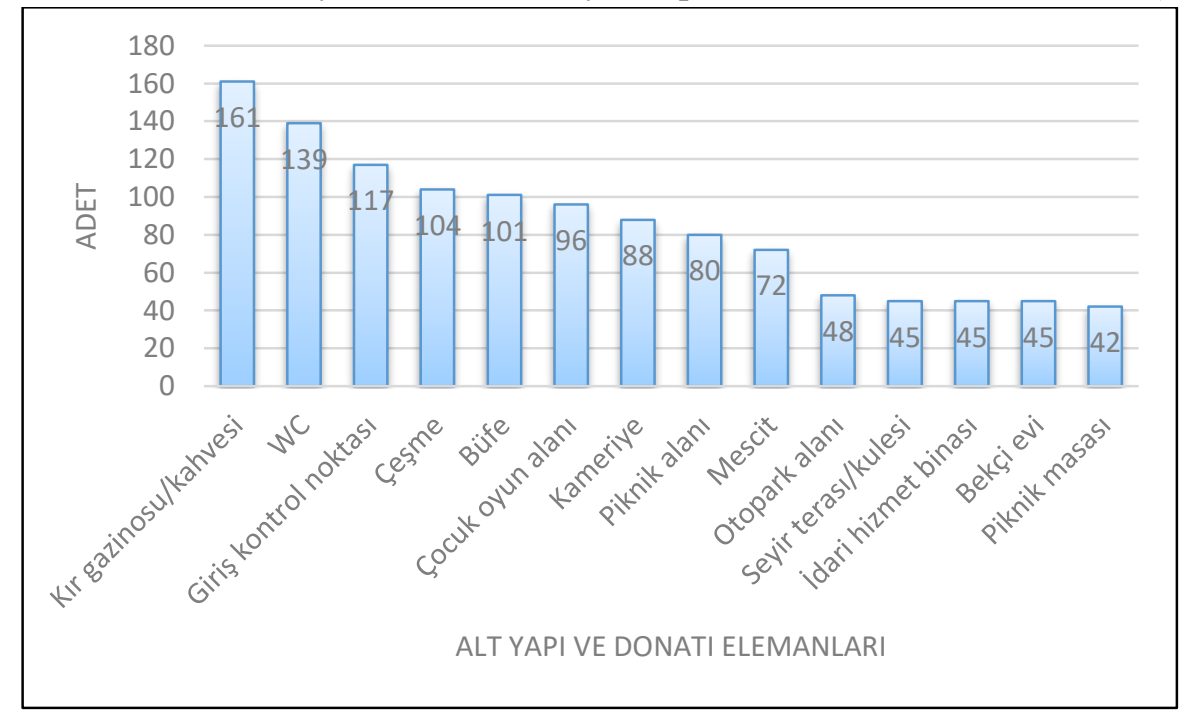

Şekil 6. Tabiat parklarındaki alt yapı ve donatı elemanları çeşitliliği 
Fiziksel alt yapı ve donatı elemanı varlığı bakımından tabiat parkları irdelendiğinde Bolu'da yer alan Abant Gölü Tabiat Park1 toplamdaki 134 öğeden 54'ünü içermektedir. Yine Karadeniz Bölgesi'nde Giresun ilimizde yer alan Kuzalan Tabiat Parkı 31 öğe ile ikinci sırada yer almaktadır. Malatya'daki Turgut Özal Tabiat Parkı ise sahip olduğu 28 farklı öğe çeşidi ile üçüncü sırada yer almaktadır. Şekil 7'de 20'nin üzerinde altyapı ve donatı elemanına sahip tabiat parkları görülmektedir.

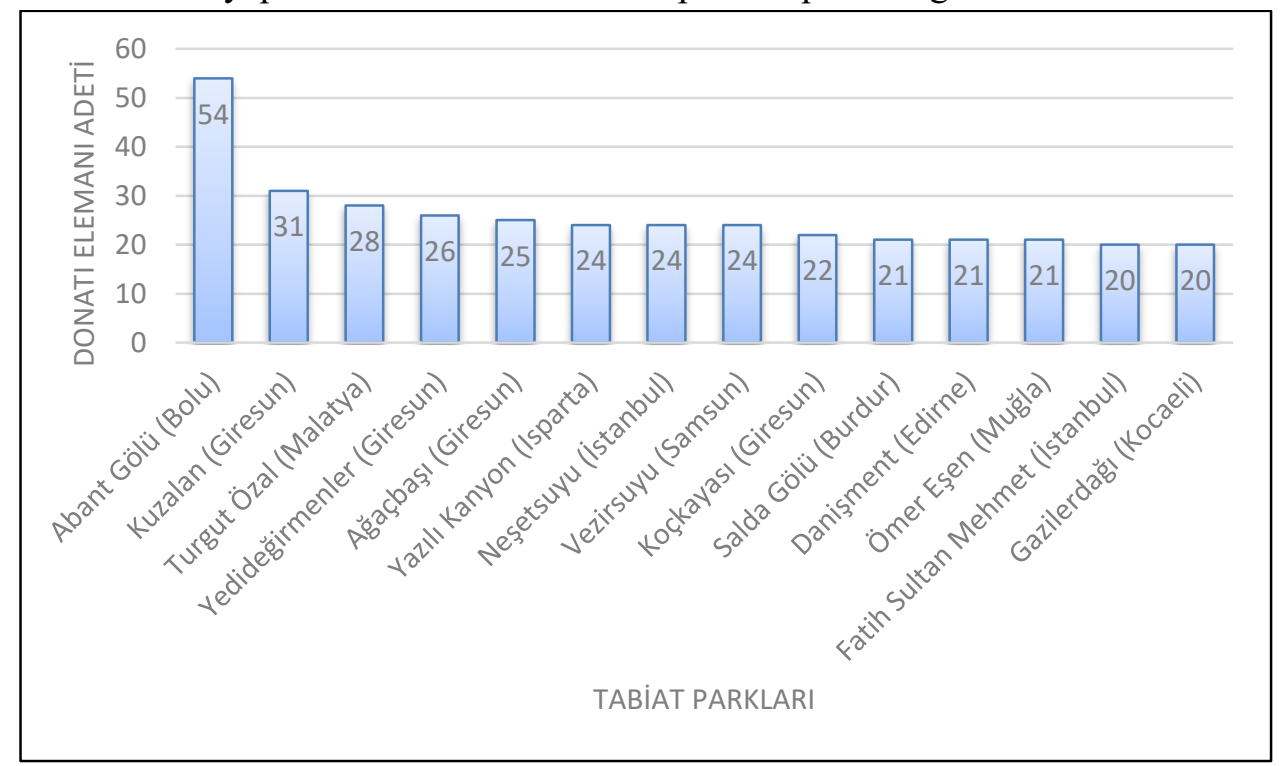

Şekil 7. Alt yapı ve donatı elemanı zenginliği açısından tabiat parkları

Türkiye'deki tabiat parkları sahip oldukları alt yap1 ve donat1 elemanları bakımından değerlendirildiklerinde, Akdeniz, Ege, Marmara ve Karadeniz bölgelerinin birbirlerine benzer yapıda ve sayıda oldukları görülürken; Doğu Anadolu ve Güneydoğu Anadolu bölgelerinde ise bu sayının oldukça düşük olduğu görülmektedir. Şekil 8 'teki kutu grafiği incelendiğinde, bölgelerin medyan değerlerinin birbirine yakın olduğu (9-10) anlaşılmaktadır. Güneydoğu Anadolu ve Doğu Anadolu bölgelerindeki tabiat parklarının daha yeni tesis edilmelerinden dolayı alt yapı ve donatı elemanı ile ilgili eksikliklerinin varlığı dikkat çekmektedir.

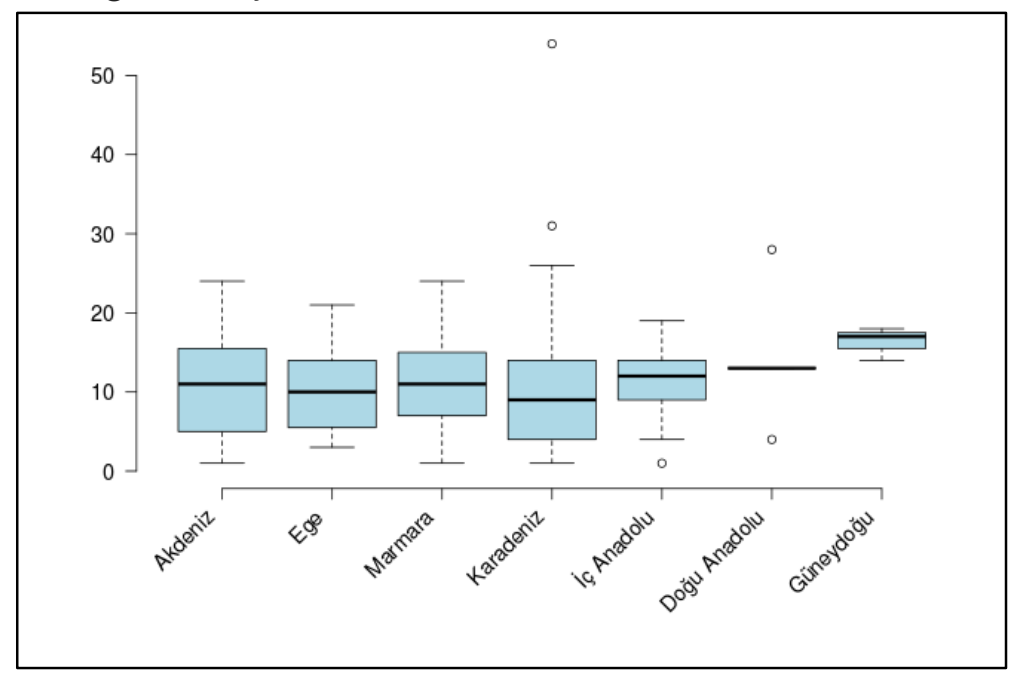

Şekil 8. Bölgelere göre tabiat parklarının dağılımı ve alt yapı elemanları açısından zenginliği

\section{Tartışma ve Sonuç}

Bu çalışmada Türkiye'deki tabiat parklarının rekreasyonel aktiviteleri ile sahip oldukları alt yapı ve donatı elemanları açısından analizi ve değerlendirilmesi yapılmıştır. Buna göre Türkiye genelinde en 
fazla tabiat parkı bulunan il İstanbul (26) olup, bunlardan 15 tanesinin doğal sit varlığına sahip olduğu görülmektedir. Kapladıkları alan açısından tabiat parkları değerlendirildiğinde ise Balıkesir ilinde bulunan Ayvalık adaları tabiat parkının 19624 ha. ile en büyük tabiat parkı olduğu tespit edilmiştir.

Yapılan analiz ve değerlendirmeler sonucunda 194 adet parkın aktivite ve alt yapı özelliklerine ilişkin bilgilere ulaşılmıştır. Buna göre, incelenen tabiat parklarında toplam 53 farklı rekreatif aktivite yapıldığı tespit edilmiştir. Türkiye'deki tabiat parklarında en yaygın olarak yapılabilen aktiviteler ise sırasıyla; doğa yürüyüşü $(\% 72,34)$, fotoğrafçılık $(\% 63,83)$, piknik $(\% 59,57)$, çadırlı kampçılık $(\% 31,49)$, bisiklet sporu $(\% 30,64)$, yaban hayatı gözlemciliği $(\% 27,23)$ ve günübirlik kullanım $(\% 24,68)$ şeklinde sıralanmaktadır. Tabiat parklarındaki aktivitelerin zenginliği açısından bakıldığında ise her tabiat parkının ortalama 5-6 farklı aktiviteye olanak sağladığı ve bunun neredeyse her bölge için geçerli bir değer olduğu anlaşılmaktadır. Bununla birlikte, bazı tabiat parklarında 20'ye yakın aktivitenin yapılabildiği görülmektedir. Korunan alanlardaki rekreasyon aktivitelerinin çeşitliliği bu alanların rekreasyonel açıdan tercih edilebilirliğinde önemli bir etkendir. Bununla birlikte, bu alanlardaki etkinliklerin alanın doğal ve kültürel peyzaj değerlerinin sürdürülebilir yönetimine uygun şekilde planlanması gerekmektedir. Nitekim, Gül ve ark. (2005)'in Gölcük Tabiat Parkı'nın rekreasyon uygunluk analizi ile potansiyel alanlarının belirlenmesini konu alan çalışmalarında, parkın sadece $\% 10$ birim karesinin rekreasyonel tesis ve etkinlik için çok uygun olduğu belirtilmiştir.

Bununla birlikte tabiat parklarındaki alt yapı ve donatı elemanlarının yeterli düzeydeki varlığı kullanıcıların rekreasyonel memnuniyeti üzerinde doğrudan etkili olup (Uzun ve ark. 2019), korunan alanlardaki rekreasyon mekanlarında yoğun bir şekilde kullanılmaktadır (Aksu 2015). Çalışmamızda değerlendirilen tabiat parklarını alt yapı özellikleri ve donatılar açısından incelediğimizde ise 114 farklı donatı ve alt yapı elemanının kaydedildiği görülmüştür. İncelenen tabiat parklarında en yaygın olarak bulunan alt yapı ve donatılar sırasıyla; Kır gazinosu/kahvesi/lokantası (\%89), WC (\%77), Giriş kontrol noktası (\%65), Çeşme (\%57), Büfe (\%56) ve Çocuk oyun alanı (\%53) şeklindedir. Alt yapı ve donatı elemanları açısından incelendiğinde en zengin alt yapının 54 öğe ile Abant Gölü Tabiat Parkına ait olduğu görülmektedir. Ülkemizdeki tabiat parklarında yapılan çalışmalarda alt yapı ve donatılara yönelik olarak; tanıtım ofisi eksikliği (Öztürk ve Gül 2020, Polat ve Polat 2016) ve güvenlik birimi/hizmetleri problemleri (Birinci ve ark. 2016, Öztürk ve Gül, 2020) olduğu vurgulanmaktadır. Benzer şekilde çalışmamızda da bu alt yapı ve donatı elemanlarının eksikliği dikkat çeken bir konu olmuştur. Veriler değerlendirildiğinde incelenen tabiat parklarının sadece 36 tanesinde alan içinde dağılmış halde güvenlik noktalarının tesis edildiği görülmektedir. Aynı şekilde ziyaretçi tanıtım merkezi bulunduran tabiat parkı sayısı da 22 olarak belirlenmiştir.

Tabiat parkları sahip oldukları doğal ve kültürel nitelikleri ile zengin bir rekreasyon imkanı sunarak öne çıkan alanlardır. Bununla birlikte bu alanların ziyaretçiler ve yerel halk tarafından bilinmesini sağlayacak bilgilendirici ve bulundukları peyzajı tanıtıcı birimlere/donatılara ve etkinliklere yeterince sahip olmadığı görülmektedir. Bu durum ülkemizdeki tabiat parkları ile ilgili çalışmalarda da (Birinci ve ark. 2016, Polat ve Polat, 2016, Başkaya 2017, Öztürk ve Gül 2020) vurgulanan bir tespit olarak bilinmektedir. Tabiat parklarının doğa ve peyzaj koruma açısından daha etkin bir araç olarak kullanılması için tanıtım ofislerinin/donatılarının tüm tabiat parkları için yaygınlaştırılması önerilmektedir. Ayrıca bazı tabiat parklarında eğitsel amaçlarla desteklenmiş ekolojik turlar (Boraboy Tabiat Parkı, Davulbaztepe Tabiat Parkı, Oluközü Tabiat Parkı) resim çizme aktivitesi (Abant Gölü Tabiat Parkı, Ayıkayası Tabiat Parkı, Vezirsuyu Tabiat Parkı), tabiat eğitimi (Cemal Tural Tabiat Park1, Altıparmak Tabiat Parkı) doğa temalı şenlikler (Balamba Tabiat Parkı, Göztepe Tabiat Parkı) gibi rekreasyonel aktiviteler de dikkat çekmektedir. Bu aktivitelerin, her tabiat parkının sunduğu potansiyele 
göre yaygınlaştırılması da korunan alanların ve koruma farkındalığının artmasını sağlayacak stratejilere katkı sağlayacaktır.

Tabiat parklarının büyük bir kısmının aynı zamanda doğal sit niteliğine de sahip olduğu da dikkat çeken bir başka husus olmuştur. Surat ve ark. (2014)'ün Borçka Karagöl Tabiat Parkı'nın rekreasyonel kullanımını konu alan çalışmalarında, korunan alanların ekolojik, kültürel ve doğal yaklaşım doğrultusunda planlandıklarında, halkın rekreasyonel gereksinimlerini karşılayacak yeterli birer kaynak oldukları sonucuna varılmıştır. Benzer şekilde Akten ve Gül (2014)'ün Gölcük Tabiat Parkı örneğinde yaptığı çalışma sonucunda, parkta kontrolsüz ve bilinçsiz yapılan rekreasyon ve turizm amaçlı kullanımlar sonucunda mevcut kaynak değerlerinin olumsuz etkilendiği görülmüsştür. Bu nedenle alanın yönetim planının yapılması ve rekreasyonel aktiviteler için de mekânsal taşıma kapasitesinin belirlenmesinin gerektiği sonucuna varılmıştır. Atmış ve ark. (2020)'nin Batı Karadeniz Bölgesi'ndeki 9 tabiat parkında gerçekleştirdikleri çalışma sonucunda, tabiat parkı kullanıcılarının çoğunluğunun geldikleri yerin bir korunan alan olduğunu bilmedikleri ve bu parklara ait tanıtımların yetersiz olduğu sonucuna varmışlardır. Benzer şekilde Sezer ve Bekdemir (2017)'nin Kuzalan Şelalesi Tabiat Parkı'nı konu alan çalışmalarında; koruma-kullanma dengesine dikkat edilmesi durumunda rekreasyonel aktivitelerin gerçekleştirilebilmelerinin mümkün olabileceği söylenmiştir. Şahbaz ve Altınay (2015)'in Türkiye'deki Milli Parkların rekreasyon aktiviteleri açısından değerlendirilmesini konu alan çalışmalarında ise; parkların özelliklerine göre rekreasyonel olarak kullanımlarının farklı olduğu, kullanımlarının ağırlıklı olarak bir bölgede yoğunlaştığı ve bundan ötürü de doğal kaynaklarda tahribatlar olduğu sonucuna varılmıştır. Benzer şekilde çalışmamızda rekreasyonel kullanımın çok daha yoğun olduğu ve özellikle doğal sit özelliği gösteren tabiat parklarında kullanımlardan kaynaklanan olumsuzlukların var olabileceği göz önüne alınarak planlama süreçlerinde dikkat edilmesi gereklidir.

Sonuç olarak, tabiat parkları, ülkemizdeki rekreasyon ihtiyacının karşılanmasında etkin ve yaygın bir araç olarak kullanılmaya başlamış bir statü olarak karşımıza çıkmaktadır. Bununla birlikte, bu alanlardaki turizm/rekreasyon aktiviteleri bu alanların korunmasına gerekçe oluşturan doğal ve kültürel kaynak değerleriyle çelişebildiği (Akten ve Gül 2014) bilinen bir gerçekliktir. Tabiat parklarındaki rekreasyon aktivitelerinin doğal ve kültürel kaynak değerleri ile uyumlu (Akten ve Gül 2014), yeterli düzeyde ve doğayla uyumlu malzemelerden tasarlanan estetik alt yapı ve donatılarla desteklenmiş (Aksu 2015), ziyaretçilere yönelik doğa koruma farkındalığını sağlayacak niteliklerle geliştirilmesi; korunan alanların misyonunu yerine getirmesinde büyük katkı sağlayacaktır.

\section{Kaynaklar}

Aksu, Ö. (2015). Korunan Doğal Rekreasyon Alanlarında Donatı Elemanlarının Tasarımları: Altındere Vadisi Milli Parkı Örneği. Kastamonu University Journal of Forestry Faculty, 15(2), 267-278.

Akten, S., Gül, A. (2014). Korunan Doğal Alanlarda Ziyaretçilerin Olası Etki Düzeyleri Önlem ve Standartların Belirlenmesi (Gölcük Tabiat Parkı Örneği), SDÜ Orman Fakültesi Dergisi, 15: 130-139.

Altunöz, Ö., Tırıl, A., Arslan, Ö.E. (2014). Hamsilos Tabiat Parkı'nın Rekreasyon Potansiyelini Belirlemeye Yönelik Bir Araştırma, Journal of Recreation and Tourism Research (JRTR) 2014, 1 (1) 20-38.

Atmış, E., Günşen H.B., Yıldız, D. (2020). Tabiat Parklarının Korunan Alan Statülerinin Değerlendirilmesi: Batı Karadeniz Örneği, Turkish Journal of Forestry, 21(2): 148-158.

Başkaya, Z. (2017). Küçükelmalı Tabiat Parkı'nın (Pazaryeri-Bilecik) Eko-Turizm Ve Rekreasyonel Potansiyeli Açısından Değerlendirilmesi. Asos Journal The Journal of Academic Social Science 5(60): 164-188.

Birinci, S., Zaman, M., Bulut, İ. (2016). Limni Gölü Tabiat Parkının (Gümüşhane) Rekreasyon Potansiyeli. Journal of International Social Research, 9(46). 
Dal, İ., Karayılmazlar, S.A. (2019). Balamba Tabiat Parkı Açık Hava Rekreasyon Potansiyelinin Değerlendirilmesi, UBAK Uulslararası Bilimler Akademisi, 55-68.

Gül, A., Örücü, K., Karaca, Ö. (2005). Korunan Alanlarda Rekreasyon Uygunluk Analizi ile Potansiyel Alanlarının Belirlenmesi (Gölcük Tabiat Parkı Örneği), Korunan Doğal Alanlar Sempozyumu, 8-10 Eylül, SDÜ Isparta.

Kaptan Ayhan, Ç. (2019). Ayazmapınarı Tabiat Parkı'nın (Bayramiç, Çanakkale) Rekreasyonel Potansiyelinin Belirlenmesi Üzerine Bir Araştırma, Cilt 7, Sayı 1, 219 - 228.

Özçalık, M. ve Kumru, S.N. (2019). Kapiçam tabiat parkı'nın gülez yöntemine göre rekreasyon potansiyelinin belirlenmesi. Turkish Journal of Forest Science, 3(2): 129-141.

Öztürk, B.Ö., Gül, A. (2020). Başpınar Tabiat Parkı'nın Rekreasyonel Planlama Açısından İrdelenmesi, Mimarlık Bilimleri ve Uygulamaları Dergisi, 5(1): 11-34.

Polat, S ve Aktaş Polat, S. (2016). Rekreasyonel tabiat parklarının korunan alanlar kapsamında incelenmesi: Mersin ili örneği, Social Sciences.

Sezer, İ., Bekdemir, Ü. (2017). Kuzalan Şelalesi Tabiat Parkı'nın Coğrafi Özellikleri ile Ekoturizm ve Rekreasyon Olanakları Bakımından İncelenmesi, Turkish Studies, Vol 12/29, 505-544.

Surat, H., Surat, B.Z., Özdemir, M. (2014). Korunan Alanların Rekreasyonel Kullanımı ve Yerel Halkın Farkındalığı: Borçka Karagöl Tabiat Parkı Örneği, II. Ulusal Akdeniz Orman ve Çevre Sempozyumu, 22-24 Ekim, Isparta.

Şahbaz, R.P., Altınay, M. (2015). Türkiye'deki Milli Parkların Rekreasyon Faaliyetleri Açısından Değerlendirilmesi, Journal of Tourism and Gastronomy Studies, 125-134.

Tekin, H., Erdönmez, C., Özgüç Erdönmez, İ. M., Kart Aktaş, N., Bekdemir, A. P., Öztoprak, Ö., Tekşen, S. (2014). Tabiat Parkı - Mesire Yeri ( Orman İçi Dinlenme Yeri) Kavramları ve Tabiat Parkı Belirleme Kriterleri Üzerine Yeniden Yapılandırma Önerisi: Belgrat Ormanı Örneği. Orman Genel Müdürlüğü Marmara Ormancılık Araştırma Enstitüsü Müdürlüğü Projesi. 135s. İstanbul.

Uzun, A., Oğlakçı, B., Yiğit R. (2019). Değirmen Boğazı Tabiat Parkı Donatı Elemanlarının ve Ziyaretçilerin Rekreasyonel Memnuniyetinin Değerlendirilmesi, II. Uluslararası Coğrafya Eğitim Kongresi (UCEK-2019). Eskişehir Osmangazi Üniversitesi, 3-5 Ekim 2019, Eskişehir.

URL-1. TC. Cumhurbaşkanlığı Mevzuat Bilgi Sistemi, www.mevzuat.gov.tr (Erişim tarihi: 20/07/2021).

URL-2. Doğa Koruma ve Milli Parklar Genel Müdürlüğü, www.tabiat.gov.tr (Erişim tarihi: 10/04/2021). 